\title{
Педагогика
}

УДК 53

DOI: 10.17277/voprosy.2015.01.pp.055-060

\section{ALTERNATIVE METHOD OF SOLVING PROBLEMS IN PHYSICS}

\author{
V. B. Vyazovov, A. A. Egorov \\ Tambov State Technical University, Tambov \\ Reviewed by Doctor of Technical Sciences, \\ Professor O. S. Dmitriev
}

Key words and phrases: non-standard methods; school tasks in physics; technique of the solution.

\begin{abstract}
This paper considers original non-standard methods of methods for solving problems from different sections of school physics; these methods enable to avoid the use of complex mathematical operations. The problems are not really difficult and can be used for additional lessons in general education schools.
\end{abstract}

Solving problems in the course of Physics is an essential element of study. In practice students aren't explained the methods and ways of solving problems, they are even not always shown the algorithm of problem-solving. In physics there are many original unusual methods of problem-solving which will be considered further. In order to develop creative abilities and critical thinking it is important to be able to solve a problem by several methods and to analyze the received solution.

There are some problems in physics which require defining the maximum or minimum values of something. Approaches to the solution of such problems can be quite different (logical conclusions, use of physical laws, knowledge of ranges of change of some constants, etc.). But sometimes it is possible to receive the formula expressing dependence of the required physical quantity on some parameter. In simple cases it is visible at what values of parameter the necessary value is reached. And it is possible to use the inequality corresponding to the demanded condition [1].

Вязовов Виктор Борисович - кандидат физико-математических наук, доцент кафедры «Физика»; Егоров Андрей Анатольевич - кандидат педагогических наук, доцент кафедры «Физика», e-mail: egorovtstu@mail.ru, ТамбГТУ, г. Тамбов.

УНИВЕРСИТЕТ им. В.И. ВЕРНАДСКОГО. №1(55). 2015. 


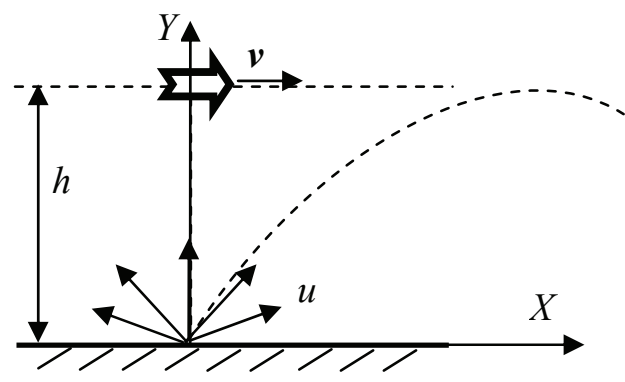

Fig. 1. Scattering of splinters at explosion of a bomb
Here are the two examples:

1. The aircraft flying horizontally with $v$ speed drops a bomb. Find the minimum appropriate height of bombing (for splinters not to strike the aircraft) if the speed of splinters scattering be $u$ and the resistance of air is neglected (Fig. 1).

Solution: As the resistance of air is neglected, the falling bomb is always under the aircraft. Therefore, it explodes on the earth directly under the aircraft. The splinters formed at the explosion have various directions. But to get to the aircraft the splinter has to be in the same plane with it (plane of a drawing) and to have a speed projection to the $X$-axis that is equal to the speed of the aircraft

$$
u_{x}=v .
$$

So, the speed projection to $Y$-axis is $u_{y}=\sqrt{u^{2}-v^{2}}$.

The splinter won't reach the aircraft if $u_{y}^{2}<2 g h$.

Consequently, $h_{\min }=\frac{u^{2}-v^{2}}{2 g}$.

2. A body slides off the top of a smooth inclined plane without the initial speed (Fig. 2), the plane basis length be $l$. What is the minimum time of the body movement?

Solution: Let the corner at the plane basis be $\alpha$. It is known that a body moves on the smooth plane with the acceleration $a=g \sin \alpha$. The length of the inclined plane is $L=\frac{l}{\cos \alpha}=\frac{1}{2} a t^{2}$. Consequently, $t=\sqrt{\frac{2 l}{g \sin \alpha \cos \alpha}}=\sqrt{\frac{4 l}{g \sin 2 \alpha}}$. It's obvious, that $t_{\min }=2 \sqrt{\frac{l}{g}}$, if $\sin 2 \alpha=1$.

But sometimes it is necessary to solve the problem by means of higher mathematics methods.

And now imagine a 9th or 10th grade student of a general education school who doesn't know about any derivatives but while preparing for various level competitions he/she is given such problems. There are two ways: 1) to study

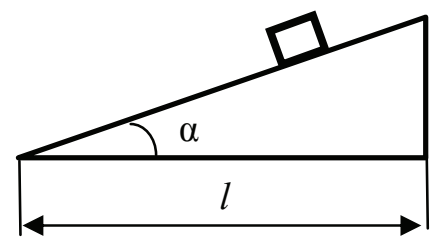

Fig. 2. Body on the inclined plane

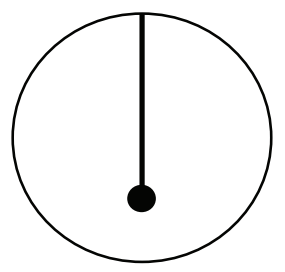

Fig. 3. Ball in the sphere 
the principles of mathematical analysis individually, that is very promising; 2) to analyze the received expressions using the known data on algebra, geometry and trigonometry [2]. In this paper, we offer some examples from different units of the school course of Physics. The tasks aren't really difficult and they can be used at the extra classes at a general education school.

1. The sphere with the mass be $m$ is suspended on a weightless inextensible thread in the top point inside the other sphere with the radius be $R$ (Fig. 3). What can be the maximum energy of the first sphere fluctuations if it shouldn't touch the surface of the other sphere?

Solution: Let the thread length be L. For the energy of the sphere fluctuations to get maximum the first sphere has to rise at fluctuations by $h$ height which is much different from balance position, i.e. practically touching the bigger sphere surface (Fig. 4), and $h=L(1-\cos \alpha)$. It is obvious, that $L=2 R \cos \alpha$. Consequently, $h=L\left(1-\frac{L}{2 R}\right)=L-\frac{L^{2}}{2 R}$. This expression gets the maximum at $L=R$ (the parabola top coordinates are known). Therefore $h_{\max }=\frac{R}{2}$ and $E_{\text {max }}=E_{p \max }=m g h_{\max }=\frac{1}{2} m g R$.

To solve the following problems we need to remind a popular inequality. Let $x$ be a positive number. It is obvious, that $\left(\sqrt{x}-\frac{1}{\sqrt{x}}\right)^{2} \geq 0$. Then, $x+\frac{1}{x} \geq 2$.

If the expression has the appearance $a x+\frac{b}{x}$, then putting a multiplier $\sqrt{a b}$ outside the brackets we receive

$$
\sqrt{a b}\left(\sqrt{\frac{a}{b}} x+\frac{1}{\sqrt{\frac{a}{b}} x}\right) \geq 2 \sqrt{a b} .
$$

2. Two resistors are connected in parallel. What minimum current can flow in the unbranched part of the chain if the current at the consecutive connection of these resistors is $2 \mathrm{~A}$ ? The voltage $U$ in both cases is identical $\left(I_{\min }=8 \mathrm{~A}\right)$.

Solution: The current $I$ at the parallel connection in the unbranched part of the chain is $\frac{U}{R_{1}}+\frac{U}{R_{2}}$. At the consecutive connection $U=I_{\text {cons }}\left(R_{1}+R_{2}\right)$. Eliminating $U$ from the equations we receive:

$$
\begin{gathered}
I=I_{\text {cons }} \frac{\left(R_{1}+R_{2}\right)^{2}}{R_{1} R_{2}}=I_{\text {cons }}\left(\frac{R_{1}}{R_{2}}+\frac{R_{2}}{R_{1}}+2\right) \geq \\
\geq 4 I_{\text {cons }} ; \\
I_{\text {min }}=8 \mathrm{~A} .
\end{gathered}
$$

Finally, we offer one more popular problem which permits different solutions.

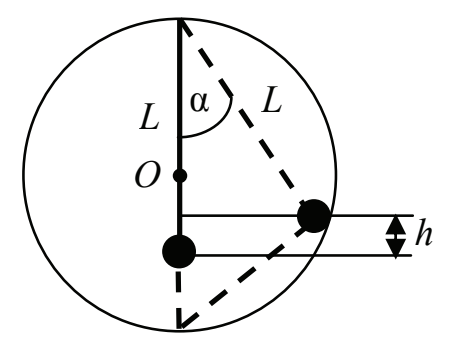

Fig. 4. Additional plotting 


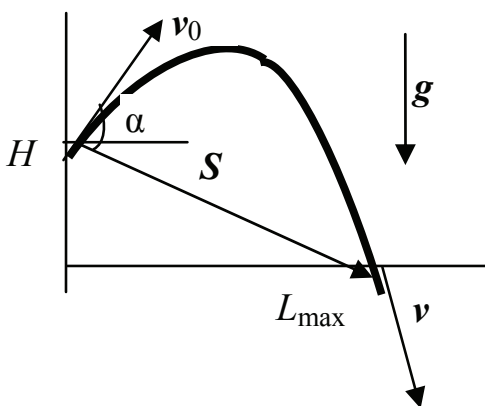

Fig. 5. Main designations (first way)

3. The body is thrown from the height of $H$ over an earth surface with $v$ speed under a corner to the horizon (Fig. 5). What is the greatest range $L_{\max }$ of the body flight?

Solution: Let $v$ be the body speed before it blows on the earth. According to the energy conservation law $v^{2}=v_{0}^{2}+2 g H$. Let the body movement vector be $S$. It is obvious that the more $|\boldsymbol{S}|$ the more $L$. Let's use the known ratios:

$$
\boldsymbol{S}=\frac{1}{2}\left(\boldsymbol{v}_{0}+\boldsymbol{v}\right) t \text { and } \boldsymbol{v}-\boldsymbol{v}_{0}=\boldsymbol{g} t .
$$

Squaring them we get:

$$
\begin{gathered}
S^{2}=\frac{1}{4}\left(v_{0}^{2}+v^{2}+2\left(\boldsymbol{v}_{0} \boldsymbol{v}\right)\right) t^{2} \\
v_{0}^{2}+v^{2}-2\left(\boldsymbol{v}_{0} \boldsymbol{v}\right)=g^{2} t^{2} .
\end{gathered}
$$

Let's eliminate the time from the equations:

$$
S^{2}=\frac{1}{4 g^{2}}\left(v_{0}^{2}+v^{2}+2\left(v_{0} v\right)\right)\left(v_{0}^{2}+v^{2}-2\left(v_{0} v\right)\right)=\frac{\left(v_{0}^{2}+v^{2}\right)-4\left(v_{0} v\right)^{2}}{4 g^{2}} .
$$

The $S$ highest value will be at $\left(\boldsymbol{v}_{0} \boldsymbol{v}\right)=0$ and $S_{\max }=$ $=\frac{1}{2 g}\left(v_{0}^{2}+v^{2}\right)=\frac{2 v_{0}^{2}-2 g H}{2 g}=\frac{v_{0}^{2}}{g}-H$.

The greatest range $L_{\max }$ of the flight can be found using Pythagorean Theorem:

$$
L_{\max }=\sqrt{S_{\max }^{2}-H^{2}}=\frac{v_{0}}{g} \sqrt{v_{0}^{2}-2 g H} .
$$

This problem has one more interesting solution. Let's carry $\boldsymbol{v}_{0}$ and $\boldsymbol{v}$ vectors from the point of the body fall and connect their ends by $\boldsymbol{g} t$ vector (Fig. 6) [3]. The square of the received triangle can be expressed as $S=\frac{1}{2} g t v_{0} \cos \alpha$. The

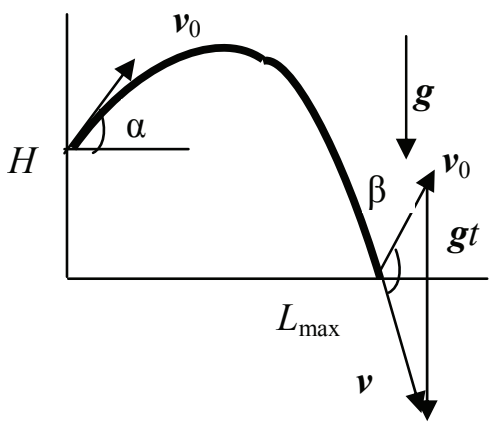

Fig. 6. Main designations (second way) flying range is $L=\left(v_{0} \cos \alpha\right) t$. This expression coincides with expression of $S$ to a constant multiplier $\frac{2}{g}$, i.e. they reach the maximum simultaneously. But the square of the triangle can be presented as $\frac{1}{2} v_{0} v \cos \beta . \quad$ As $\quad v=\sqrt{v_{0}^{2}+2 g H}$ and it doesn't depend on $\alpha$ corner so the greatest square of $\alpha$ (and so the greatest range) is 
$\cos \beta=1$. Therefore, $\beta=\frac{\pi}{2}, \quad \operatorname{tg} \alpha=\frac{v_{0}}{v} \quad$ and $L_{\max }=\frac{2}{g} S_{\max }=\frac{2}{g} \frac{1}{2} v_{0} v=\frac{v_{0} v}{g}=$ $=\frac{v_{0}}{g} \sqrt{v_{0}^{2}-2 g H}$.

The following problems can be offered for individual solving.

1. Two resistors, one has the electrical resistance of $5 \Omega$ and the other allocates the thermal power of $20 \mathrm{~W}$, are connected in parallel. What minimum current can flow under such conditions in the unbranched part of the chain?

Answer: $I_{\min }=2 \sqrt{\frac{P}{R}}=4$ A.

2. Two condensers, one has the capacity of $5 \mathrm{~F}$ and the other has the energy of $5 \mathrm{~J}$, are connected in parallel. What minimum charge can be on this battery?

Answer: $q_{\min }=2 \sqrt{\frac{2 W}{C}}=4 \mathrm{C}$.

3. Two springs, one has a rigidity of $k$ and the other has the energy of $E_{p}$, are connected in parallel. What can be the minimum force for stretching the springs?

Answer: $F_{\min }=2 \sqrt{2 E_{p} k}$.

4. Two bodies move in one direction with identical speed. One has the mass of $m$ and the other has the kinetic energy of $E_{k}$. What is the minimum total impulse of these bodies?

Answer: $p_{\min }=2 \sqrt{2 E_{k} m}$.

5. There is a vertical cylindrical vessel with water filled up to $H$ height on a horizontal surface. What $h$ distance from a bottom of a vessel a small opening is to be pierced at so that the water stream flying range is the greatest?

Answer: $h=H$.

\section{References}

1. Шапиро, А. И. Оригинальные методы решения физических задач / А. И. Шапиро, В. А. Бодик. - Киев : Освіта, 1992. -118 с.

2. Ащеулов, С. В. Задачи по элементарной физике / С. В. Ащеулов, В. А. Барышев. - 2-е изд., испр. - Л. : Изд-во Ленингр. ун-та, 1975. - 192 с.

3. Бутиков, Е. И. Физика для поступающих в вузы : учеб. пособие / Е. И. Бутиков, А. А. Быков, А. С. Кондратьев. - 2-е изд., испр. - М. : Наука, Гл. ред. физ.-мат. лит., 1982. $-608 \mathrm{c}$.

\section{References}

1. Shapiro A.I., Bodik V.A. Original'nye metody resheniya fizicheskikh zadach (Original methods for solving physical problems), Kiev: Osvita, 1992, 118 p.

2. Ashcheulov S.V., Baryshev V.A. Zadachi po elementarnoi fizike (Objectives of elementary physics), Leningrad: Izdatel'stvo Leningradskogo universiteta, 1975, 192 p. 
3. Butikov E.I., Bykov A.A., Kondrat'ev A.S. Fizika dlya postupayushchikh v vuzy (Physics for entering universities), Mosxow: Nauka, Glavnaya redaktsiya fizikomatematicheskoi literatury, 1982, $608 \mathrm{p}$.

Методика решения задач по физике альтернативными способами

\section{В. Б. Вязовов, А. А. Егоров}

ФГБОУ ВПО «Тамбовский государственный технический университет», г. Тамбов

Ключевые слова и фразы: методика решения; нестандартные методы; школьные задачи по физике.

Аннотация: Рассмотрены оригинальные нестандартные методы решения задач из разных разделов школьной физики, которые позволяют избежать применения сложных математических операций. Задачи могут быть использованы при проведении дополнительных занятий в обычных классах.

С В. Б. Вязовов, А. А. Егоров, 2015 